\title{
Crises, Volatility, and Growth
}

\author{
Enisse Kharroubi
}

How do volatility and liquidity crises affect growth? When credit is constrained, a bias toward short-term debt can arise in financing long-term investments, generating maturity mismatches and leading potentially to liquidity crises. The frequency of liquidity crises ("abnormal" volatility) and the volatility of growth ("normal" volatility) are found to have independent negative effects on growth. Financial development however dampens the growth cost of volatility, but only in the case of normal volatility. The growth cost of volatility therefore depends critically on the composition of normal and abnormal volatility, the latter being more costly for growth. JEL codes: E44, G30, O16.

After the financial crises of the 1990s many voices rose to explain that the causes of these crises were new (Radelet and Sachs 1998; Corsetti, Pesenti, and Roubini 1999). Indeed, the usual features known to trigger crises (unsustainable government economic policies; Krugman 1979) were absent or could not by themselves imply such severe crises (Baig and Goldfajn 2002). Instead, new phenomena were in play, such as the large short-term debt that firms had accumulated before the crisis (table 1).

Several explanations have since been brought forward to explain this buildup in corporate imbalances-two in particular. According to the first, "crony capitalism" can explain the imbalances (Krugman 1999), because in distorting individual incentives, it encouraged firms to make inefficient decisions (about investments, risks, and so on). The implicit insurance under crony capitalism prompted agents to believe that they could benefit from the low cost of short-term debt and that the government would help them overcome potential illiquidity.

Enisse Kharroubi is an economist at the Bank of France; his email address is enisse. kharroubi@banque-france.fr. The author is grateful to Arturo Galindo, Jim de Melo, Norman Loayza, Henri Pagès, Romain Rancière, Mathias Thoenig, Thierry Tressel, Thierry Verdier, two anonymous referees for their useful comments and suggestions, as well as to the participants in the seminars at the Bank of France; the Department and Laboratory of Applied and Theoretical Economics (DELTA), École Normale Supérieure, Paris; the European Economics Association Summer Meetings; the Money Macro and Financial Research Group Conference; the International Monetary Fund-Pompeu Fabra University Conference; the Theory and Method of Macroeconomics (T2M) Conference; and the Venice University Summer School. The views are those of the author and do not necessarily reflect those of the Bank of France.

THE WORLD BANK ECONOMIC REVIEW, pp. 1-22

doi:10.1093/wber/lhm015

(C) The Author 2007. Published by Oxford University Press on behalf of the International Bank for Reconstruction and Development / THE WORLD BANK. All rights reserved. For permissions, please e-mail: journals.permissions@oxfordjournals.org 
Table 1. Aggregate Financial Indicators for Nonfinancial Firms, 1995-96 (median)

\begin{tabular}{lccc}
\hline Economy & Debt-equity ratio & \\
\hline China & Current ratio $^{\mathrm{b}}$ & Quick ratio $^{\mathrm{c}}$ \\
Hong Kong, China & 0.553 & 1.321 & 0.968 \\
Korea, Rep. of & 0.420 & 1.352 & 0.947 \\
Malaysia & 2.485 & 1.078 & 0.773 \\
Pakistan & 0.114 & 1.296 & 0.913 \\
Philippines & 0.999 & 0.993 & 0.510 \\
Taiwan, China & 0.239 & 1.370 & 0.961 \\
Thailand & 0.195 & 1.587 & 1.037 \\
United States & 0.915 & 1.143 & 0.697 \\
\hline
\end{tabular}

Note: ${ }^{\text {a }}$ Ratio of total debt to the market value of the firm.

${ }^{b}$ Ratio of current assts to current liabilities-that is, with maturity of less than one year.

${ }^{\mathrm{c}}$ Ratio of current assets minus inventories to current liabilities.

Source: Claessens, Djankov, and Nenova 2000.

The second explanation is the "original sin" hypothesis (Eichengreen and Haussman 1999). Financial imbalances such as those displayed in table 1 are due to the inability of firms to choose their financial portfolios. Although firms know the risks, they are pushed to adopt "dangerous" financing strategies as the only way to get capital from financial markets.

Although both explanations may be reasonable and explain the vulnerability of countries to financial crashes, they are incomplete and fairly ad hoc in their foundations. In the crony capitalism explanation, the implicit insurance and the collusion links between firm managers and politicians are exogenous. There is no positive theory of crony capitalism. For original sin, what needs to be explained is why it might be relevant for developing economies but not for developed economies. For example, the share of long-term debt in total corporate debt increases with economic development (Demirgüç-Kunt and Maksimovic 1999) (figure 1).

Understanding how economic and financial development modifies financial contracts requires understanding original sin. This article has two aims. First, it uses an explicit framework to explain why private agents use risky financial strategies. Second, it explores the macroeconomic consequences of private financial strategies for growth and volatility. To do this, it studies how the maturity of firm debts is determined.

The mechanism is as follows. When contracts are imperfectly enforceable, lenders impose a bias toward short-term debt on the debt portfolio of borrowers investing in long-term activities. For lenders the problem with long-term debt lies in the freedom it leaves the borrower. In a long-term debt contract there is at least one date between the contract date and the payment date, and the borrower can choose to shirk at that interim date. In this model the borrower can decide to stop a project and reinvest the capital in a less efficient 
Figure 1. Income Per Capita and Proportion of Long-term Debt

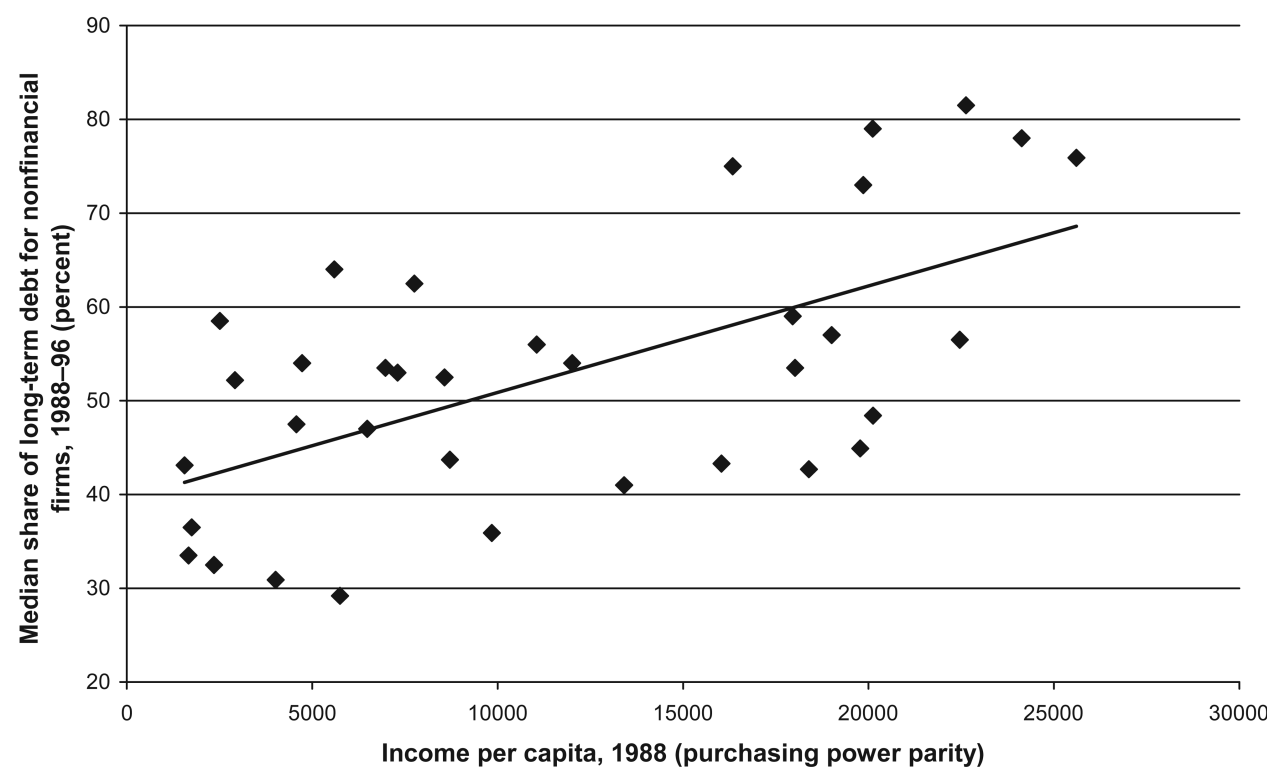

Note: Each point represents a country.

Source: Claessens, Djankov, and Lang 1998; Penn World Tables 6.1.

storage technology, eventually defaulting on the long-term loan. To prevent borrowers from doing so, lenders can increase the share of short-term debt in borrower debt portfolios. Lenders then have effective controlling power because they can sanction the borrowers by asking for short-term debt repayments, if the borrowers stop their project. ${ }^{1}$ Although this mechanism solves a microeconomic incentive problem, it generates a global coordination issue when borrowers rely heavily on short-term debt. Why? if lenders agree to roll over short-term debts, borrowers are then able to carry out their long-term projects, their final return is large, and they do not have incentives to default on long-term loans. It is then rational for lenders to accept short-term debts rollover. However, if lenders refuse to roll over short-term debts, borrowers are then unable to carry out their long-term projects, their final return is low, and they have incentives to default on long-term loans. It is then rational for lenders to refuse short-term debts rollover. So both the situations where lenders agree and situations where they refuse to roll over short-term debts are equilibria, and borrowers can be forced to stop their projects because lenders are unable to coordinate to avoid inefficient runs on short-term debts.

This framework produces three results. First, the higher the probability of a run, the lower the average growth rate of the economy. This is intuitive because growth is lower when a run on short-term debts triggers liquidation of

1. This amounts to assuming that lenders can observe borrowers who stop their project. 
long-term projects. Second, an increase in the volatility of long-term projects' productivity reduces growth. As the volatility of the return on entrepreneurs' projects increases their average return, it also reduces the return on lenders' technology, which always dominates at the aggregate level. Third, a reduction in credit constraints affecting entrepreneurs tends to reduce the probability of a run and thus to reduce the growth cost of volatility. On the basis of a data set for a large number of countries, the article provides empirical evidence to confirm these results.

This article relates to four strands of the literature. First, liquidity issues are studied in Diamond and Dybvig's (1983) seminal paper. Since there is a possibility of panics in the banking sector because liabilities are short term and assets are long term, banks can act as pools of liquidity to stop these panics. Closer to this article is Diamond (1991), who shows how firms' financial choices may help reduce informational asymmetries with lenders. In Diamond (1991) firms with good prospects are more likely to issue short-term debt because their probability of confronting liquidity shocks is smaller. Flannery (1986) and Kale and Noe (1990) also consider financial choices as signals of project quality. This article's approach is different, however, because firm heterogeneity plays no role. It is the nature of long-term projects (the possibility of stopping them interim) that prompts firms to borrow short term. Closest to the approach of this article is the paper by Rey and Stiglitz (1993), who show that short-term contracts give lenders the power to monitor borrowers. The argument here differs, however, by stressing the disciplining effect of short-term debt rather than its monitoring power. It then shows that the disciplining effect of short-term debt is not cost-free because it may come with multiple equilibria and inefficient project terminations due to run on the short-term liabilities of firms.

Second, this article is close to work that explains micro- or macroeconomic stylized facts using corporate financial contracts. Albuquerque and Hopenhayn (2004) study how optimal maturity debt contracts explain the dynamics of firm development. Rodrik and Velasco (1999) explain why developing economies can rationally accumulate unsustainable amounts of short-term debt. The idea is that accumulating short-term debt with illiquid projects increases the price of long-term debt because the premium on long-term debt depends positively on the amount of short-term debt.

Third, this article is related to the literature on the macroeconomic impact of capital market imperfections (Bernanke and Gertler 1989; Greenwood and Jovanovic 1990; Greenwald and Stiglitz 1993; Acemoglu and Zilibotti 1997; Kiyotaki and Moore 1997; Aghion, Banerjee, and Piketty 1999), which points out that capital market imperfections can generate or exacerbate fluctuations.

Fourth, this article is related to the literature on growth and volatility. As the common wisdom, influenced by Ramey and Ramey (1995), points to a negative relationship, some arguments support a positive relationship (Jones, Manuelli, and Sachetti 1999; Tornell, Westermann, and Martinez 2004). The 
contribution here is to show that as the different sources of volatility identified all having a negative effect on growth, the growth cost of volatility depends on the composition of volatility between normal and abnormal volatility, the latter much more costly for growth.

Section I establishes the microeconomics of the capital market. Section II applies this framework to a macroeconomic model and derives the main results for growth and volatility. Section III provides empirical evidence. Section IV draws conclusions.

\section{A Two-period Model of the Credit Market}

Consider a risk-neutral borrower-entrepreneur with initial capital normalized to one living two periods and maximizing end-of-life consumption. In time $t$, the entrepreneur invests in a long-term illiquid project. Investing $k_{t}$ units of capital in a long-term project at time $t$ yields $A \min \left(k_{t} ; k_{t+1}\right)$ units of capital at time $t+2, k_{t+1}$ being the volume of capital still in the project at time $t+1$. The project is illiquid because extracting capital at time $t+1$ can reduce the return of the overall project

$$
A=\left\{\begin{array}{l}
\bar{R} \text { if } \min \left(k_{t} ; k_{t+1}\right) \geq(1-\eta) k_{t} \\
\underline{R} \text { if } \min \left(k_{t} ; k_{t+1}\right)<(1-\eta) k_{t}
\end{array}\right.
$$

with $0<\eta<1$. At time $t$ the entrepreneur can borrow a volume of capital $\mu$ from a pool of risk-neutral investors. The share of short-term debts (which need to be repaid after one period) in total borrowing is $\alpha$, and the share of long-term debts (which must be repaid after two periods) in total borrowing is $1-\alpha$. The gross interest rate on short-term debts is $r_{s}$, and the gross interest rate on long-term debts is $r_{l}$. Short-term debts are perfectly enforceable, but long-term debts are not; entrepreneurs can default on their long-term debts. ${ }^{2}$

In time $t+1$ the entrepreneurs can extract capital from their project. Extracting one unit of capital from the illiquid project yields one unit of capital. With that capital the entrepreneurs can pay back their short-term debts. But that can reduce the return on the illiquid project from $\bar{R}$ to $\underline{R}$.

In time $t+2$, the entrepreneurs reap the benefit of their investment and decide whether to default on their long-term debts. The marginal cost of defaulting on long-term debts is $\bar{\tau}$ if $A=\bar{R}$ and $\underline{\tau}$ if $A=R$. The entrepreneur faces a moral hazard, $\bar{R}>\underline{R}$ but $\bar{R}-\bar{\tau}<\underline{R}-\tau$.

At time $t$, the entrepreneur invests $k_{t}=1+\mu$ and pays back $\alpha \mu r_{s}$ at time $t+1$, so $k_{t+1}=1+\mu-\alpha \mu r_{s}$. If the entrepreneurs then pay back their

2. The difference in enforceability between short- and long-term contracts is assumed to simplify the exposition of the model. Assuming a similarly imperfect enforceability would not change the mechanism or the results of the model. It would simply add another incentive-compatibility constraint, formally very close to the illiquidity constraint. 
long-term debts, they reap a profit

$$
\pi=\left(1+\mu-\alpha \mu r_{s}\right) \bar{R}-(1-\alpha) \mu r_{l}
$$

By contrast, if the entrepreneurs default on long-term liabilities, they do not pay for its long-term debts $(1-\alpha) \mu r_{l}$, but they face the cost associated with default. Their profit is then

$$
\pi^{\prime}=\left(1+\mu-\alpha \mu r_{s}\right)(R-\tau)
$$

Lenders then need to propose financial contracts that preclude entrepreneurs from defaulting on their liabilities. The next proposition details these contracts. Proposition 1

Noting that $\tau=\bar{R}-(\underline{R}-\underline{\tau})$ and assuming that $r_{l}>\tau r_{s}$, time $t$ incentivecompatible debt portfolios $(\alpha, \mu)$ satisfy

$$
\frac{1+\mu}{\mu} \geq(1-\alpha) \frac{r_{l}}{\tau}+\alpha r_{s}
$$

If an entrepreneur satisfies at time $t+1$ the illiquidity constraint $\min \left(k_{t} ; k_{t+1}\right)$ $\geq(1-\eta) k_{t}$, lenders can reduce the share of short-term debts from $\alpha$ to $\beta$ with

$$
\beta \geq \frac{1}{r_{l}-\bar{\tau} r_{s}}\left[r_{l}-\bar{\tau} \frac{1+\mu}{\mu}\right]^{+}
$$

Proof: See the appendix.

This framework produces three remarks. First, as long as the illiquidity constraint is satisfied, a higher share of short-term debt $\alpha$ raises the entrepreneur's borrowing capacity $\mu$. Second, a "larger" moral hazard, in the sense of a lower $\tau$, reduces the entrepreneur's borrowing capacity. This implies that an entrepreneur with a given volume of borrowing $\mu$ has to bear a higher proportion of short-term debt under a larger moral hazard. Lenders therefore impose a "bias" toward short-term debt because they use short-term debt as a disciplining device, to make sure that entrepreneurs do not take advantage of a moral hazard. Third, lenders can reduce or withdraw this bias when the moral hazard problem disappears-that is, after they observe that borrowers have not extracted capital beyond the illiquidity constraint. In this case lenders transform some of the short-term debts into long-term ones because an entrepreneur who proceeds with a high-return project has no incentives to default on longterm loans. ${ }^{3}$ In contrast, if the entrepreneurs decide to extract too much capital

3. The expression for short-term debt rollover $\beta$ is valid if it is assumed that the market for debt rollover is competitive. In this case the interest rates on rolled-over short-term debt and on long-term debt are identical, and $\beta$ is the minimal value that verifies equation (2). 
Credit limit

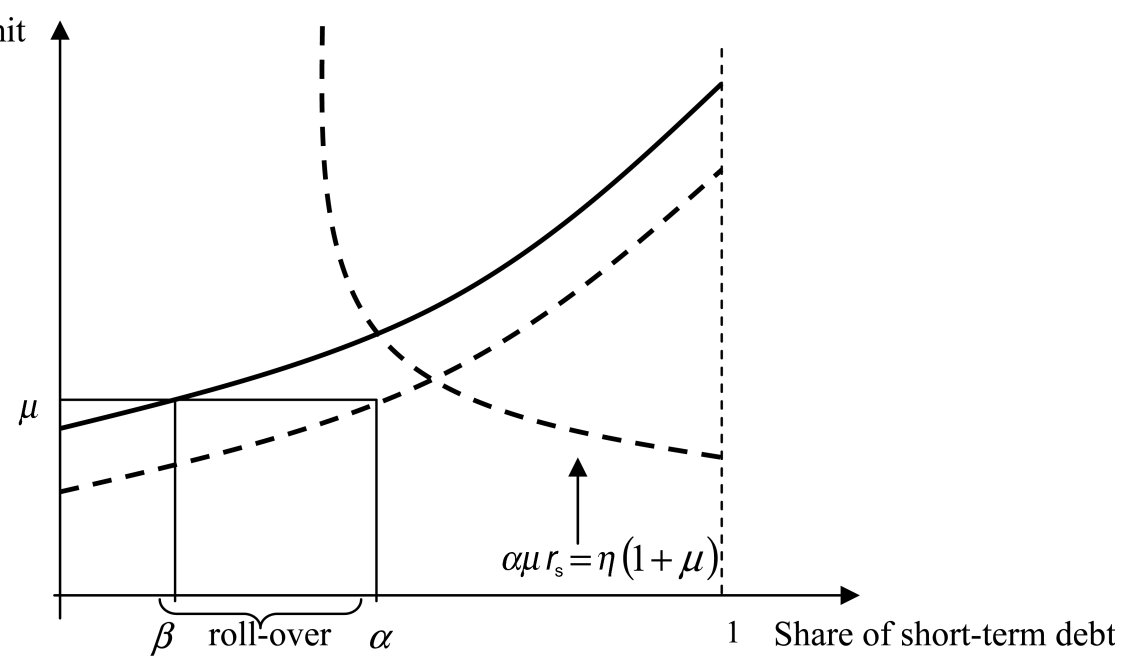

Source: Author's analysis based on data described in the text.

from their project, they have incentives to default on long-term loans, so lenders have to ask for full short-term debt repayments (figure 2).

\section{The Macroeconomic Model}

This section introduces this capital market framework in a macroeconomic model to shed light on the aggregate consequences of the structure of financial contracts.

\section{Agents and Technologies}

Consider a single-good economy with two types of risk-neutral agents: entrepreneurs (type $e$ agents) and lenders (type $l$ agents). There is a continuum of unit mass of each type of agent. All agents live for two periods and maximize their expected end-of-life profits. All have access to a storage technology, $y_{t+1}=r k_{t}$, with $r \geq 1$. Moreover, entrepreneurs have access to a long-term illiquid technology, $y_{t+2}=A \min \left\{k_{t} ; k_{t+1}\right\}$, with

$$
A=\left\{\begin{array}{l}
R \text { if } \min \left(k_{t} ; k_{t+1}\right) \geq(1-\eta) k_{t} \\
0 \text { if } \min \left(k_{t} ; k_{t+1}\right)<(1-\eta) k_{t}
\end{array}\right.
$$

So entrepreneurs who violate the illiquidity constraint $\min \left(k_{t} ; k_{t+1}\right) \geq$ $(1-\eta) k_{t}$ can extract all their capital from their long-term illiquid project at time $t+1$ and invest in the storage technology. Entrepreneurs have the best opportunities in the economy $R>r^{2}$. They can thus borrow capital from lenders. The capital market is exactly the same as the previous section. 
Entrepreneurs can borrow with short- (one-period) and long-term (two-period) debt contracts. Long-term contracts are imperfectly enforceable; default is possible, but an entrepreneur needs to pay a marginal cost on the final output $(\bar{\tau}$ when the entrepreneur can carry out an illiquid long-term project and $\tau$ when the entrepreneur violates the illiquidity constraint and reinvests in the storage technology). Entrepreneurs are subject to a moral hazard $R>r$ and $R-\bar{\tau}<r-\tau$.

\section{Timing of the Model}

At the start date entrepreneurs make investments and borrowing choices (short- or long-term debt). Lenders deliver loans to entrepreneurs and they invest in the storage technology the capital they have not lent. At the interim date, short-term debts are paid back or rolled over, and entrepreneurs may violate the illiquidity constraint. At the final date the returns on the different projects are realized according to what happened at the interim date, and longterm and rolled-over short-term debts are paid back.

\section{Optimal Debt Portfolios}

THE SAFE FINANCING STRATEGY. When lenders ask the entrepreneurs to pay $\alpha \mu r_{s}$, the entrepreneurs are still able to carry out their illiquid project, if and only if $\alpha \mu r_{s} \leq \eta(1+\mu)$. It is incentive-compatible for lenders to ask only for $\beta \mu r_{s}$ as short-term debt repayments because the entrepreneurs are always able to proceed with their illiquid project and therefore have no incentive to deviate. The program of the entrepreneurs is then

$$
\max _{\alpha, \mu}\left(1+\mu-\beta \mu r_{s}\right) R-(1-\beta) \mu r_{l}
$$

$$
\operatorname{such} \text { that }\left\{\begin{array}{l}
\frac{1+\mu}{\mu} \geq \max \left\{(1-\alpha) \frac{r_{l}}{\tau}+\alpha r_{s} ; \alpha \frac{r_{s}}{\eta}\right\} \\
\left(r_{l}-\bar{\tau} r_{s}\right) \beta \geq\left[r_{l}-\bar{\tau} \frac{1+\mu}{\mu}\right]^{+}
\end{array}\right.
$$

\section{Preposition 2}

If $\eta<\bar{\eta} \equiv \bar{\tau}-\tau / r_{l}-\tau r_{s} r_{s}$, the entrepreneur optimal borrowing choices are

$$
\alpha^{*}=\frac{\eta r_{l}}{\eta r_{l}+(1-\eta) \tau r_{s}} \text { and } \mu^{*}=\frac{\eta r_{l} / r_{s}+(1-\eta) \tau}{r_{l}-\eta r_{l} / r_{s}-(1-\eta) \tau}
$$

Proof: See the appendix.

The inequality $\eta<\bar{\eta}$ means that if the entrepreneur's technology is sufficiently illiquid, supplying incentives to deter entrepreneurs from liquidating long-term projects is costly, because the entrepreneur's borrowing capacity is strictly lower than it would be without the interim moral hazard. The case $\eta \geq \bar{\eta}$ is 
therefore uninteresting since there is no tradeoff between individual incentives and firm profits. So it is assumed that $\eta<\bar{\eta}$.

THE RISKY FINANCING STRATEGY. When lenders ask the entrepreneurs to pay $\alpha \mu r_{s}$, the entrepreneurs can still carry out their illiquid project if and only if $\alpha \mu r_{s} \leq$ $\eta(1+\mu)$. Similarly, if lenders ask the entrepreneurs to pay only $\beta \mu r_{s}$, the entrepreneurs are able to carry out their project with a large return if and only if $\beta \mu r_{s} \leq \eta(1+\mu)$. So two different outcomes are possible when

$$
\beta \mu r_{s} \leq \eta(1+\mu) \leq \alpha \mu r_{s}
$$

If lenders ask the entrepreneurs to pay only $\beta \mu r_{s}$ (some short-term debts are rolled over), the entrepreneurs can proceed with their illiquid project. It is then incentive-compatible to roll over some of the short debts and ask only for $\beta \mu r_{s}$ as short-term debt repayments. In contrast, if lenders ask the entrepreneurs to pay all their short-term debts, $\alpha \mu r_{s}$, the entrepreneurs cannot proceed with their illiquid project. It is then rational for lenders to ask for full short-term debt repayments because the entrepreneurs would otherwise default on any short-term debt that may be rolled over. ${ }^{4}$

Note that $p$ is the probability that lenders decide to ask entrepreneurs to pay $\alpha \mu r_{s}$ as short-term debts repayments and $1-p$ is the probability that lenders decide to ask entrepreneurs to pay $\beta \mu r_{s}{ }^{5}$ The entrepreneur's expected profit is $\pi=(1-p)\left[\left(1+\mu-\beta \mu r_{s}\right) R-(1-\beta) \mu r_{l}\right]+p\left[\left(1+\mu-\alpha \mu r_{s}\right) r-(1-\alpha) \mu r_{l}\right]$. So, the program ${ }^{6}$ of the entrepreneur is

$$
\max _{\alpha, \mu}\left(1+\mu-\beta \mu r_{s}\right)[p r+(1-p) R]-\mu\left[r_{l}+\beta\left(r_{s} R-r_{l}\right)(1-p)\right.
$$

$$
\begin{aligned}
& \left.+\alpha\left(r_{s} r-r_{l}\right) p\right] \\
& \text { such that }\left\{\begin{array}{c}
\max \left\{(1-\alpha) \frac{r_{l}}{\tau}+\alpha r_{s} ; \alpha \frac{r_{s}}{\eta}\right\} \leq \frac{1+\mu}{\mu} \leq \alpha \frac{r_{s}}{\eta} \\
\left(r_{l}-\bar{\tau} r_{s}\right) \beta \geq\left[r_{l}-\bar{\tau} \frac{1+\mu}{\mu}\right]^{+}
\end{array}\right.
\end{aligned}
$$

4. Due to illiquidity entrepreneurs' technology works as an increasing return to scale technology; the higher the volume of capital that remains in the project, the higher the final return. Moreover, the higher the return, the less likely the entrepreneur is to default and the less risky is a short-term debt rollover for lenders.

5. Lenders base their decision to ask for short-term debt repayment or to roll over short-term debt on an extrinsic sunspot.

6. The case where entrepreneurs pay for their debts if and only if they can carry out their illiquid project until maturity (not considered here) is always dominated; entrepreneurs have to pay for default costs and there are no benefits for the debt portfolio (size being identical and risk premium being actuarially fair). 
And the solution is

$$
\alpha^{*}=\frac{\bar{\tau}}{\bar{\tau}-\underline{\tau} r_{l}-\underline{\tau}_{s}} \text { and } \mu^{*}=\frac{\bar{\tau}}{r_{l}-\bar{\tau}}
$$

Note that $\left(\alpha_{i} ; \mu_{i}\right)$ is the solution to program $P_{i}$ and $\pi_{i}$ is the entrepreneur's optimal profit associated with $\operatorname{program} P_{i}$. That leads to the following proposition.

\section{Proposition 3}

When $\eta<\bar{\eta}$, the entrepreneur chooses the safe strategy if and only if $p>q$ with $q=\left(\mu_{2}-\mu_{1}\right)\left(R-r_{l}\right) /\left(1+\mu_{2}\right)(R-r)+\alpha_{2} \mu_{2}\left(r r_{s}-r_{l}\right)$

Proof: Comparing $\pi_{1}$ and $\pi_{2}$ yields the proposition.

The entrepreneurs simply make financial decisions according to the probability that they may be compelled to liquidate their long-term project. If the entrepreneurs anticipate a low roll over probability on their short-term liabilities - that is, a high probability of a run - they borrow a few short-term debts to preclude any run on their liabilities. In contrast, if the rollover probability is high, entrepreneurs choose more short-term debt, with the portfolio composition ensuring complete rollover in case lenders agree to roll over shortterm claims.

Having determined the optimal financial choices of firms, the article next examines how these choices affect macroeconomic variables, especially growth and volatility.

\section{Growth and Macroeconomic Fluctuations}

Note that the entrepreneur's initial wealth is $w_{e}$ and lender's initial wealth is $w_{l}$. Assuming that $w_{l} \geq \mu_{2} w_{e}$, short- and long-term interest rates are such that $r_{s}=r$ and $r_{l}=r^{2}$, and the entrepreneur's optimal debt portfolio is such that

$$
\mu^{*}=\left\{\begin{array}{l}
\mu_{2} \text { if } p<q \\
\mu_{1} \text { if } p>q
\end{array}\right.
$$

Two types of equilibria are possible. When the probability $p$ is low the entrepreneur chooses program 2, the risky strategy, and the probability of a run is $p$. In contrast, when the probability $p$ is large the entrepreneur chooses program 1 , the safe strategy, and the probability of a run is 0 . It is now pos-

$$
g_{s}=\frac{\left(w_{l}-\mu^{*} w_{e}\right) r^{2}+\left(1+\mu^{*}\right) w_{e} A_{s}\left(\mu^{*}\right)}{w_{l}+w_{e}}
$$


where $A_{b}\left(\mu_{1}\right)=A_{l}\left(\mu_{1}\right)=R$ and $A_{b}\left(\mu_{2}\right)=R$ with probability $1-p$ and $A_{l}\left(\mu_{2}\right)=r$ with probability $p$. The following proposition can then be derived.

\section{Proposition 4}

The average growth rate of the economy $m$ and the standard deviation of the growth rate $\sigma$ are

$$
m=\frac{\left(w_{l}-\mu^{*} w_{e}\right) r^{2}+\left(1+\mu^{*}\right) w_{e}\left[p A_{l}\left(\mu^{*}\right)+(1-p) A_{b}\left(\mu^{*}\right)\right]}{w_{l}+w_{e}}
$$

$$
\sigma^{2}=p(1-p)\left[\frac{\left(1+\mu^{*}\right) w_{e}}{w_{l}+w_{e}}\left[A_{b}\left(\mu^{*}\right)-A_{l}\left(\mu^{*}\right)\right]\right]^{2}
$$

Proof: The mean and the standard deviation can be computed using the expression for $g_{s}$.

Growth volatility depends only on investments in the illiquid technology financed with portfolios $\left(\alpha_{2} ; \mu_{2}\right)$ because those with portfolios $\left(\alpha_{1} ; \mu_{1}\right)$ are never subject to a run. Average growth and growth volatility depend on three items: the entrepreneur's borrowing capacity $\mu^{*}$, the volatility in the return on illiquid projects $R-r$, and the probability $p$ of a run. The following result can then be derived.

\section{Proposition 5}

Assuming that $w_{l} \geq \mu_{2} w_{e}$ and $p<q$, the probability $p$ of a run and the volatility $R-r$ in the return on the entrepreneur's projects reduce average growth and increase growth's volatility. The probability $p$ amplifies the negative effect of the volatility $R-r$ on growth.

Proof: Deriving the expression of $m$ and $\sigma$ with respect to $p$ and $R-r$ yields the result.

Both the probability $p$, which relates to the entrepreneur's financial choices, and the volatility in the return on entrepreneur's projects $R-r$, which is exogenous, contribute to lower growth. These two sources of aggregate volatility reduce growth through independent channels; the probability of a run reduces the average return on the entrepreneur's projects, whereas the volatility $R-r$ on the return on entrepreneur's projects increases the average return on the entrepreneur's projects but imposes a negative effect on the storage technology that always dominates at the aggregate level. Moreover, there is an amplification channel; a higher probability of liquidity crisis tends to raise the growth cost of the volatility in the productivity of the entrepreneur's projects. So a higher borrowing capacity $\mu_{1}$, by reducing the upper threshold of the probability $p$, will tend to reduce the growth cost of volatility in the productivity of the entrepreneur's projects.

The next part looks at the empirical evidence to determine whether these two different channels are empirically relevant. 
To test the validity of the theoretical predictions, data from three sources are considered: the Penn World Tables (Heston, Summers, and Aten 2002), the World Development Indicators database (World Bank 2005), and the World Bank Financial Structure and Economic Development Database (Beck, Demirgüc-Kunt, and Levine 1999). Macroeconomic variables come from the first two data sets, and the financial data from the third. The sample includes 87 countries for 1971-2000. ${ }^{7}$ Following Loayza and Hnatkovska (2004), the cross-country growth regressions are carried out with average GDP per capita growth, the dependent variable, and the usual growth determinants (average private credit to GDP, average population growth, and initial GDP per capita), the independent variables. Volatility measures are added to test the predictions of the model. The regressions can be expressed as

$$
\frac{y_{i}^{2000}-y_{i}^{1971}}{30}=\alpha+\beta x_{i}+\delta z_{i}+\varepsilon_{i}
$$

where $y_{i}^{t}$ represents the $\log$ of GDP per capita in country $i$ in year $t, \alpha$ is a constant, $x_{i}$ is a vector of the usual growth determinants, and $z_{i}$ represents the vector of variables that the model predictions are based on.

The previous section divided growth volatility into the volatility of returns on the illiquid technology and the probability $p$ of a run. To apply this distinction empirically, two measures of volatility are considered: the volatility of growth (the standard deviation of GDP per capita growth) and the frequency of low-growth episodes (the number of years when GDP per capita growth is below a given threshold). This threshold is equal to average GDP per capita growth minus one standard deviation of GDP per capita growth for each country. This captures the fact that crises are usually abnormal forms of volatility not captured by the standard deviation of GDP per capita growth. Symmetrically, the frequency of high-growth episodes is also considered the number of years when GDP per capita growth is above average GDP per capita growth plus one standard deviation of GDP per capita growth).

Before going into econometric estimations, two things are worth noticing based on the correlations among the variables (see the appendix). First, all

7. The sample consists of Algeria, Argentina, Australia, Austria, Bangladesh, Belgium, Benin, Bolivia, Brazil, Burkina Faso, Burundi, Cameroon, Canada, Central African Republic, Chad, Chile, China, Colombia, Democratic Republic of Congo, Costa Rica, Côte d'Ivoire, Denmark, Dominican Republic, Ecuador, Egypt, El Salvador, Finland, France, Ghana, Greece, Guatemala, Haiti, Honduras, Hong Kong, China, Hungary, India, Indonesia, Ireland, Italy, Japan, Kenya, Liberia, Madagascar, Malawi, Malaysia, Mauritania, Mexico, Morocco, Nepal, Netherlands, New Zealand, Nicaragua, Niger, Nigeria, Norway, Pakistan, Panama, Papua New Guinea, Paraguay, Peru, Philippines, Portugal, Puerto Rico, Republic of Congo, Republic of Korea, Rwanda, Senegal, Sierra Leone, Singapore, South Africa, Spain, Sri Lanka, Sudan, Sweden, Switzerland, Syria, Thailand, Togo, Tunisia, United Kingdom, United States, Uruguay, Venezuela, R.B., Zambia, and Zimbabwe. 
measures of volatility (growvol, lgfreq, and hgfreq) correlate negatively with average growth, although the magnitude is much lower for the frequency of high-growth episodes. Second, the correlation between the frequency of lowand high-growth episodes is positive but rather low (0.3494).

In the econometric estimations the first tested is the prediction of the model that the forms of volatility considered should all have negative impacts on growth (table 2). Regression 1 shows that the estimated coefficients on the standard variables conform to what is usually found in the literature. Regressions 2-4 test the growth effects of the different forms of volatility. The estimates confirm that growth volatility, measured by the standard deviation of GDP growth, is harmful to growth, as is the frequency of low-growth episodes. Moreover, note that the coefficient for the frequency of low-growth episodes is much more significant than its counterpart for the standard deviation of GDP per capita growth. Regression 4 shows that the variable representing the frequency of high-growth episodes is not significant.

Regressions 5 and 6 test the hypothesis that the different volatility indicators provide nonredundant information for average growth. This seems indeed to be

\section{Table 2. Growth Effects of Different Volatility Measures}

Dependent variable: GDP per capita growth

\begin{tabular}{|c|c|c|c|c|c|c|}
\hline & \multicolumn{6}{|l|}{ Regression } \\
\hline & 1 & 2 & 3 & 4 & 5 & 6 \\
\hline $\begin{array}{l}\text { Log of initial } \\
\text { GDP per } \\
\text { capita }\end{array}$ & $-0.654 *$ & $-0.729 * * *$ & $-0.624 * *$ & $-0.648 * *$ & $-0.742 * * *$ & $-0.755 * *$ \\
\hline $\begin{array}{l}\text { Population } \\
\text { growth }\end{array}$ & $-0.688 * * *$ & $-0.626 * *$ & $-0.648 * * *$ & $-0.694 * *$ & $-0.531 * *$ & $-0.512 * *$ \\
\hline Credit to GDP & $3.017 * * *$ & $2.818 * * *$ & $3.027 * * *$ & $2.996 * *$ & $2.693 * * *$ & $2.775 * *$ \\
\hline Growth volatility & - & $-0.013 *$ & - & - & $-0.220 * * *$ & $-0.214 * * *$ \\
\hline $\begin{array}{l}\text { Low-growth } \\
\text { frequency }\end{array}$ & - & - & $-0.382 * * *$ & - & $-0.500 * * *$ & $-0.528 * * *$ \\
\hline $\begin{array}{l}\text { High-growth } \\
\text { frequency }\end{array}$ & - & - & - & -0.023 & - & 0.077 \\
\hline $\begin{array}{l}\text { Number of } \\
\text { observations }\end{array}$ & 81 & 81 & 81 & 81 & 81 & 81 \\
\hline
\end{tabular}

*Significant at the 10 percent level; **significance at the 5 percent level; $* *$ significant at the 1 percent level.

Note: The dependent variable is average GDP per capita growth for each country in the sample over 1971-2000. Log of initial GDP per capita is the logarithm of GDP per capita in 1970 , population growth is the average population growth rate over 1971-2000, credit to GDP is the average ratio of private credit to GDP over 1971-2000, growth volatility is the standard deviation of GDP per capita growth over 1971-2000, low-growth frequency is the number of years over 1971-2000 when GDP per capita growth was below average GDP per capita growth minus one standard deviation of GDP per capita growth, high-growth frequency is the number of years over 1971-2000 when GDP per capita growth was above average GDP per capita growth plus one standard deviation of GDP per capita growth.

Source: Author's analysis is on the basis of the data described in the text. 
the case. Both regressions show that the volatility of growth and the frequency of low-growth episodes have negative and significant coefficients. Regression 6 confirms that the high-growth-frequency variable has no significance in explaining average growth. Table 2 thus validates the prediction that volatility is harmful due both to deviations around the mean (growth volatility) and to crises (frequency of low-growth episodes) that directly reduce mean growth.

The prediction that different sources of volatility tend to have cumulative negative effects on growth is tested next. In other words, does an increase in the frequency of low-growth episodes tend to raise the negative effect of volatility on average growth? Symmetrically, does an increase in volatility tend to raise the negative effect of the frequency of low-growth episodes on average growth? Added for this test are interaction terms between the three volatility variables considered in the previous regression framework (table 3 ).

Regression 1 tests the interaction of growth volatility and the frequency of lowgrowth episodes. The amplification effect is relevant; growth volatility and the frequency of low-growth episodes tend to reinforce each other in their negative growth effects. But the significance of the interaction term is low. Regression 2 shows that the interaction between growth volatility and the frequency of highgrowth episodes is not significant. In contrast, regression 3 shows that there are dampening effects between the frequency of low- and high-growth ones. This seems natural since the two variables should have, other things equal, opposite effects on average growth. Regressions 4-6 provide essentially similar results, but the significance is higher when the three different sources of volatility are introduced. In particular, regression 5 shows that a higher frequency of high-growth episodes tends to raise the growth cost of growth volatility.

To sum up, there are two different empirical results. First, both normal volatility (the standard deviation of GDP per capita growth) and abnormal volatility (the frequency of years when GDP per capita growth is below the average minus one standard deviation) have negative effects on average GDP per capita growth. Empirical estimations have shown that these two sources of volatility are nonredundant growth determinants. With a given volatility, a higher frequency of low growth reduces average GDP per capita growth. Similarly, with a given episode, frequency of low- and higher-growth volatility also reduces average GDP per capita growth.

Second, some evidence suggests that the negative growth effects of these two sources of volatility tend to reinforce each other. The negative effect on growth of the frequency of low-growth episodes seems to be amplified by a higher standard deviation of GDP per capita growth.

Before going into further evidence for these two conclusions, it is important to note that it might be argued that a higher frequency of low-growth episodes tautologically reduces average growth, the former variable being embedded in the latter. This remark misses two points. First, a higher frequency of lowgrowth episodes can be compensated for by what is called "low growth" actually being higher, with countries trading off the frequency against the severity 
TABle 3. Interaction Effects of Different Volatility Measures

620

625

Dependent variable: GDP per capita growth

\begin{tabular}{|c|c|c|c|c|c|c|}
\hline & \multicolumn{6}{|l|}{ Regression } \\
\hline & 1 & 2 & 3 & 4 & 5 & 6 \\
\hline $\begin{array}{l}\text { Log of initial GDP } \\
\text { per capita }\end{array}$ & $-0.751^{* * *}$ & $-0.767^{* * *}$ & $-0.559 * *$ & $-0.761 * * *$ & $-0.825 * *$ & $-0.653 * *$ \\
\hline Population growth & $-0.483 * *$ & $-0.596^{* * *}$ & $-0.570 * *$ & $-0.470 *$ & $-0.444^{*}$ & $-0.442 *$ \\
\hline Credit to GDP & $2.598 * * *$ & $2.708 * * *$ & $2.929 * * *$ & $2.663 * * *$ & $2.745 * * *$ & $2.446 * * *$ \\
\hline Growth volatility & 0.009 & -0.033 & - & 0.007 & -0.016 & $-0.247 * * *$ \\
\hline $\begin{array}{l}\text { Low-growth } \\
\text { frequency }\end{array}$ & -0.162 & - & $-1.080 * * *$ & -0.192 & $-0.561 * * *$ & $-1.38^{* * *}$ \\
\hline $\begin{array}{l}\text { High-growth } \\
\text { frequency }\end{array}$ & - & 0.224 & 0.550 & 0.059 & $0.490 * *$ & $-0.794 * *$ \\
\hline $\begin{array}{l}\text { Growth } \\
\text { volatility } \times \\
\text { low-growth } \\
\text { frequency }\end{array}$ & $-0.072 * * *$ & - & - & $-0.070^{*}$ & - & - \\
\hline $\begin{array}{l}\text { Growth } \\
\text { volatility } \times \\
\text { high-growth } \\
\text { frequency }\end{array}$ & - & -0.689 & - & - & $-0.093 *$ & - \\
\hline $\begin{array}{l}\text { Low-growth } \\
\text { frequency } \times \\
\text { high-growth } \\
\text { frequency }\end{array}$ & - & - & $0.166^{*}$ & - & - & $0.213 * * *$ \\
\hline $\begin{array}{l}\text { Number of } \\
\text { observations }\end{array}$ & 80 & 80 & 80 & 80 & 80 & 80 \\
\hline
\end{tabular}

*Significant at the 10 percent level; $*$ *significance at the 5 percent level; $* *$ significant at the 1 percent level.

Note: The dependent variable is the average GDP per capita growth for each country in the sample over 1971-2000. Log of initial GDP per capita is the logarithm of GDP per capita in 1970 , population growth is the average population growth rate over 1971-2000, credit to GDP is the average ratio of private credit to GDP over 1971-2000, growth volatility is the standard deviation of GDP per capita growth over 1971-2000, low-growth frequency is the number of years over 1971-2000 when GDP per capita growth was below average GDP per capita growth minus one standard deviation of GDP per capita growth, high-growth frequency is the number of years over 1971-2000 when GDP per capita growth was above average GDP per capita growth plus one standard deviation of GDP per capita growth.

Source: Author's analysis is on the basis of the data described in the text.

of low-growth episodes. If that is so, the frequency of low-growth episodes could well correlate positively with average growth. Empirical evidence suggests that this is not so. Second, a higher frequency of low-growth episodes could similarly be traded off against a higher frequency of high-growth episodes, and average growth could also correlate positively with the frequency of low-growth episodes. Once again empirical evidence shows that this does not seem to be so. For these two reasons the result that the frequency of lowgrowth episodes is bad for growth is not trivial. 
A simple way to address whether the frequency of low-growth episodes is indeed embedded in average growth is to consider the exogenous component of this measure and estimate its impact on average growth. This can be achieved with instrumental variable estimation. But before getting to these results, note that the result that both the standard deviation and the frequency of low GDP per capita growth episodes correlate negatively with average GDP per capita growth sheds light on growth theories relating average growth and growth skewness. This literature highlights that, given the negative growth effect of the standard deviation of GDP per capita growth, there is a positive growth effect from GDP per capita growth skewness, arguing that countries experiencing more frequent crises grow faster (Rancière, Tornell, and Westermann forthcoming, 2008). The empirical evidence here goes in the opposite direction, showing that the frequency of crises (low-growth episodes) does indeed always decrease growth.

Next to be determined is whether the two empirical predictions here are confirmed after the endogeneity bias is removed. Instrumental variable estimations are used to this end. Following the literature on the growth-volatility relationship, the variables are terms of trade-growth volatility, trading partners' GDP per capita-growth volatility, average trade to GDP, average share of urban population in total population, average consumer price index (CPI) inflation rate, CPI inflation rate volatility, average black market premium, black market premium volatility, a low and a high initial income dummy variables. Econometric tests confirm both the endogeneity bias of the previous estimates and the validity of this instrument set.

Regressions 1 and 2 confirm that each of the volatility measures here has significant predictive power for growth. Both variables have, as previously, a negative effect on growth. Compared with ordinary least-squares estimations, the estimated coefficient is much higher in both cases $(-0.724$ compared with -0.013 for growth volatility and -1.99 compared with -0.382 for the frequency of lowgrowth episodes). This indicates that volatility, however measured, is much more costly for growth than first found here. Regression 3 shows that the frequency of high-growth episodes has a negative impact on the average growth of GDP per capita for a given frequency of low-growth episodes. Although the significance is low, this regression confirms that there is a growth gain for countries in which growth is more stable, whether around low- or high-growth episodes.

Regressions 4 and 5 test whether the different volatility measures have independent predictive power for growth. The two regressions confirm that the exogenous component of GDP per capita growth volatility and the frequency of low GDP per capita growth episodes are costly for mean growth. As seen previously, the magnitude of the coefficients is larger than for ordinary least-squares estimates. Moreover, the estimated coefficient for the frequency of low-growth episodes is much more significant. One interpretation of this finding is that the first-order effect on the average growth of GDP per capita comes from the frequency of low-growth episodes, whereas GDP per capita growth volatility has only a second-order effect. This is confirmed by the 
magnitude of coefficients, which is four times bigger for the frequency of lowgrowth episodes than for the volatility of GDP per capita growth (regression 4). A one-standard-deviation increase in the frequency of low-growth episodes thus induces a growth loss that is more than 30 percent larger than the growth loss induced by a one-standard-deviation increase in growth volatility. ${ }^{8}$

Interaction effects have also been investigated. Regression 6 shows that the interaction between the exogenous components of GDP per capita growth volatility and the frequency of low GDP per capita growth episodes is not a significant predictor of average growth (table 4). But this article's theoretical model suggests that the growth effect of volatility depends on credit constraints. To examine this possibility, an interaction term is introduced between the volume of credit to GDP and the volatility variables (table 5). It turns out that the volume of credit to GDP significantly affects the relationship between growth and volatility when volatility is measured as the standard deviation of GDP per capita growth. But this is not so for the frequency of low-growth episodes whose growth effect is independent of the volume of credit (regressions 1 and 2).

This result is robust both to the inclusion of other alternative volatility measures and to controlling for endogeneity (regressions 3-6).

\section{Conclusions}

This article shows that macroeconomic fluctuations in the form of liquidity crises can emerge endogenously. When long-term financial contracts are imperfectly enforceable and in the presence of a moral hazard, lenders bias debt portfolios toward short-term debt to overcome the possibility of borrowers defaulting strategically. But this generates maturity mismatches between assets and liabilities and can lead to a global liquidity shortage when projects are illiquid. On the basis of this mechanism, the article shows that the relationship between volatility and growth is negative-whatever the volatility measure considered (the standard deviation of growth or the frequency of low-growth episodes) - and that the two sources of volatility tend to reinforce each other.

Empirical evidence, based on a large international data set, confirms that the two volatility sources have autonomous negative effects on growth. Financial development tends to dampen the growth cost of normal volatility (when volatility is measured as the standard deviation of GDP growth). But it does not seem to affect the growth cost of abnormal volatility (measured as the frequency of growth collapses). These results show that distinguishing different volatility sources is important for economic policy because the growth cost of volatility depends on the relative weights of normal and abnormal volatility.

8. Dispersion in the GDP per capita growth volatility variable is about three times the dispersion of the frequency of low-growth episode variables. So given the magnitude of coefficients, a one-standard-deviation increase in the frequency of low-growth episodes reduces growth by a factor of four-thirds compared with the growth loss induced by a one-standard-deviation increase in GDP per capita growth volatility. The growth loss is therefore about 30 percent larger. 
TABLE 4. Interaction Effects between the Exogenous Components of Different Forms of Volatility

Dependent variable: GDP per capita growth

\begin{tabular}{|c|c|c|c|c|c|c|}
\hline & \multicolumn{6}{|l|}{ Regression } \\
\hline & 1 & 2 & 3 & 4 & 5 & 6 \\
\hline $\begin{array}{l}\text { Log of initial } \\
\text { GDP per } \\
\text { capita }\end{array}$ & -0.695 & -0.927 & -0.892 & -0.550 & -0.608 & $-0.790 * *$ \\
\hline $\begin{array}{l}\text { Population } \\
\text { growth }\end{array}$ & 1.070 & -0.815 & -0.861 & -0.226 & -0.187 & -0.343 \\
\hline Credit to GDP & $4.587 * *$ & $4.440 * *$ & $4.269^{*}$ & $2.274 * *$ & $2.388^{* * * *}$ & $2.456 * *$ \\
\hline $\begin{array}{l}\text { Growth } \\
\text { volatility }\end{array}$ & $-0.724 * * *$ & & & $-0.364 *$ & $-0.384 *$ & -0.588 \\
\hline $\begin{array}{l}\text { Low-growth } \\
\text { frequency }\end{array}$ & - & $-1.99 * * *$ & $-1.98 * *$ & $-1.54 * * *$ & $-1.54 * * *$ & $-1.73 * *$ \\
\hline $\begin{array}{l}\text { High-growth } \\
\text { frequency }\end{array}$ & - & - & $-0.137^{*}$ & - & 0.144 & - \\
\hline $\begin{array}{l}\text { Growth } \\
\text { volatility } \times \\
\text { Low-growth } \\
\text { frequency }\end{array}$ & - & - & - & - & - & 0.048 \\
\hline $\begin{array}{l}\text { Hausman test } \\
\quad(p \text {-value })\end{array}$ & 0.00 & 0.00 & 0.00 & 0.00 & 0.00 & 0.00 \\
\hline $\begin{array}{r}\text { Sargan test } \\
\text { (p-value) }\end{array}$ & 0.47 & 0.98 & 0.97 & 0.62 & 0.49 & 0.57 \\
\hline $\begin{array}{l}\text { Number of } \\
\text { observations }\end{array}$ & 80 & 80 & 80 & 80 & 80 & 80 \\
\hline
\end{tabular}

"Significant at the 10 percent level; * significance at the 5 percent level; ** significant at the 1 percent level.

Note: The dependent variable is the average GDP per capita growth for each country in the sample over 1971-2000. Log of initial GDP per capita is the logarithm of GDP per capita in 1970 , population growth is the average population growth rate over 1971-2000, credit to GDP is the average ratio of private credit to GDP over 1971-2000, growth volatility is the standard deviation of GDP per capita growth over 1971-2000, low-growth frequency is the number of years over 1971-2000 when GDP per capita growth was below average GDP per capita growth minus one standard deviation of GDP per capita growth, high-growth frequency is the number of years over 1971-2000 when GDP per capita growth was above average GDP per capita growth plus one standard deviation of GDP per capita growth. The Hausman test indicates whether the ordinary least-squares estimation is biased, with a p-value less than 5 percent indicating bias. The Sargan test indicates whether the instrument set is valid, with a p-value greater than 5 percent indicating that the instrument set is valid.

Source: Author's analysis is on the basis of the data described in the text.

\section{Proof of proposition 1}

Consider a contract $(\alpha, \mu)$. The entrepreneurs have three options. They can pay back their debts and carry out their illiquid project until the end. Then their profit is $\pi=\left(1+\mu-\alpha \mu r_{s}\right) \bar{R}-(1-\alpha) \mu r_{l}$. They can also default on long-term debts. In this case, given that there is a moral hazard $\underline{R}-\underline{\tau}>\bar{R}-\bar{\tau}$, the entrepreneurs are better off stopping their illiquid project. Their profit is then 


\section{TABLE 5. Interaction Effects of Financial Development and Different} Volatility Measures

Dependent variable: GDP per capita growth

\begin{tabular}{|c|c|c|c|c|c|c|}
\hline & \multicolumn{6}{|l|}{ Regression } \\
\hline & 1 & 2 & 3 & 4 & 5 & 6 \\
\hline $\begin{array}{l}\text { Log of initial } \\
\text { GDP per } \\
\text { capita }\end{array}$ & $-0.728 * *$ & $-0.657 * *$ & $-0.738 * *$ & $-0.790 * * *$ & $-0.995 * *$ & $-0.965 * *$ \\
\hline $\begin{array}{l}\text { Population } \\
\text { growth }\end{array}$ & $-0.894 * * *$ & $-0.634 * *$ & $-0.774 * * *$ & $-0.506 *$ & $-0.957 * *$ & $-0.712 * *$ \\
\hline Credit to GDP & $-1.974 * * *$ & 0.871 & -1.232 & -0.079 & $-6.972 * *$ & -3.893 \\
\hline $\begin{array}{l}\text { Growth } \\
\text { volatility }\end{array}$ & $-0.724 * * *$ & - & $-0.365 * *$ & $-0.233 * * *$ & $-0.876 * * *$ & $-0.738 * * *$ \\
\hline $\begin{array}{l}\text { Low-growth } \\
\text { frequency }\end{array}$ & - & $-0.549 * *$ & $-0.384 * * *$ & $-0.721 * * *$ & - & $-0.430 * *$ \\
\hline $\begin{array}{l}\text { Growth } \\
\text { volatility } \times \\
\text { credit to GDP }\end{array}$ & $1.453 * * *$ & - & $1.199 * * *$ & - & $2.975 * *$ & $2.169 * * *$ \\
\hline $\begin{array}{l}\text { Low-growth } \\
\text { frequency } \\
\times \text { credit to } \\
\text { GDP }\end{array}$ & - & 0.537 & - & 0.685 & - & - \\
\hline $\begin{array}{l}\text { Hausman test } \\
\text { (p-value) }\end{array}$ & 一 & 一 & 一 & - & 0.00 & 0.00 \\
\hline $\begin{array}{l}\text { Sargan test } \\
(\mathrm{p} \text {-value })\end{array}$ & 一 & - & - & - & 0.56 & 0.52 \\
\hline $\begin{array}{l}\text { Number of } \\
\text { observations }\end{array}$ & 81 & 81 & 81 & 81 & 80 & 80 \\
\hline
\end{tabular}

*Significant at the 10 percent level; **significance at the 5 percent level; $* *$ significant at the 1 percent level.

Note: The dependent variable is the average GDP per capita growth for each country in the sample over 1971-2000. Log of initial GDP per capita is the logarithm of GDP per capita in 1970 , population growth is the average population growth rate over 1971-2000, credit to GDP is the average ratio of private credit to GDP over 1971-2000, growth volatility is the standard deviation of GDP per capita growth over 1971-2000, low-growth frequency is the number of years over 1971-2000 when GDP per capita growth was below average GDP per capita growth minus one standard deviation of GDP per capita growth, high-growth frequency is the number of years over 1971-2000 when GDP per capita growth was above average GDP per capita growth plus one standard deviation of GDP per capita growth. The Hausman test indicates whether the ordinary least-squares estimation is biased, with a p-value less than 5 percent indicating bias. The Sargan test indicates whether the instrument set is valid, with a p-value greater than 5 percent indicating that the instrument set is valid.

Source: Author's analysis is on the basis of the data described in the text.

$\pi^{\prime}=\left(1+\mu-\alpha \mu r_{s}\right)(\underline{R}-\underline{\tau})$. A contract $(\alpha, \mu)$ is incentive-compatible only if $\pi \geq \pi$, meaning that

$$
\frac{1+\mu}{\mu} \geq(1-\alpha) \frac{r_{l}}{\tau}+\alpha r_{s}
$$


If an entrepreneurs can carry out a project in the production technology with a debt portfolio $(\alpha, \mu)$, it is then incentive-compatible to exchange this portfolio against a portfolio $(\beta, \mu)$ if and only if $\left(1+\mu-\beta \mu r_{s}\right) \bar{R}-$ $(\alpha-\beta) \mu r_{l}-(1-\alpha) \mu r_{l} \geq\left(1+\mu-\beta \mu r_{s}\right)(\bar{R}-\bar{\tau})$. Assuming that $r_{l} \geq \bar{\tau} r_{s}$ and noting $[y]^{+}=\max (y ; 0)$, this last expression can be simplified as

$$
\left(r_{l}-\bar{\tau} r_{s}\right) \beta \geq\left[r_{l}-\bar{\tau}(1+\mu) / \mu\right]^{+}
$$

\section{Proof of proposition 2}

When $\mu \leq \bar{\tau} /\left(r_{l}-\bar{\tau}\right)$, then $\beta=0$ and the entrepreneur's profit is $\pi=(1+$ $\mu) R-r_{l} \mu$. It is strictly increasing in $\mu$. When $\mu>\bar{\tau} /\left(r_{l}-\bar{\tau}\right)$ the entrepreneur's profit is strictly lower than $\pi=(1+\mu) R-r_{l} \mu$. Hence, the solution is $\mu=\bar{\tau} /$ $\left(r_{l}-\bar{\tau}\right)$ and $\alpha^{*}=r_{l} / \tau \bar{\tau}-\tau / r_{l}-\tau r_{s}$. But due to the illiquidity constraint, this portfolio is possible if and only if $\eta \leq r_{s}(\bar{\tau}-\tau) /\left(r_{l}-\tau r_{s}\right.$. So when this last condition is not met, the entrepreneur chooses $\alpha$ and $\mu$ such that $(1-\alpha)\left(r_{l} / \tau+\right.$ $\alpha r_{s}=\alpha\left(r_{s} / \eta\right.$ and $\left(1+\mu / \mu=\alpha r_{s} \eta\right.$, to maximize the volume of capital borrowed $\mu$ while minimizing the share of short-term debt $\alpha$, which yields

$$
\alpha^{*}=\frac{\eta r_{l}}{\eta r_{l}+(1-\eta) \tau r_{s}} \text { and } \mu^{*}=\frac{\eta r_{l} / r_{s}+(1-\eta) \tau}{r_{l}-\eta r_{l} / r_{s}-(1-\eta) \tau}
$$

\section{APPENDIX}

\section{Table A-1: Summary Statistics}

Variable Number of observations Mean Standard deviation Minimum Maximum

\begin{tabular}{llllrr}
\hline growth & 85 & 1.410 & 1.924 & -4.817 & 6.935 \\
growvol & 85 & 4.661 & 3.036 & 1.632 & 21.229 \\
lrgdpch & 84 & 8.092 & 1.005 & 6.177 & 9.958 \\
hgfreq & 85 & 3.624 & 1.336 & 0 & 6 \\
lgfreq & 85 & 4.141 & 1.197 & 1 & 8 \\
dpopm & 85 & 1.915 & 0.9364 & -0.036 & 3.529 \\
pcgdpm & 82 & 0.388 & 0.333 & 0.001 & 1.518 \\
\hline
\end{tabular}

Note: The average GDP per capita growth of the sample for each country over 1971-2000 is growth, growvol is the standard deviation of GDP per capita growth over 1971-2000, lrgdpch is the logarithm of GDP per capita in 1970, hgfreq is the number of years in 1971-2000 when GDP per capita growth was above average GDP per capita growth plus one standard deviation of GDP per capita growth, lgfreq is the number of years in 1971-2000 when GDP per capita growth was below average GDP per capita growth minus one standard deviation of GDP per capita growth, $d p$ opm is the average population growth rate over 1971-2000, and $p c g d p m$ is the average ratio of private credit to GDP over 1971-2000.

Source: Author's analysis is on the basis of the data described in the text. 
TABle A-2: Correlation Table

\begin{tabular}{lrrlllll}
\hline & growth & lrgdpch & dpopm & growvol & lgfreq & hgfreq & pcgdpm \\
\hline growth & 1.0000 & - & - & - & - & - & - \\
lrgdpch & 0.3186 & 1.0000 & - & - & - & - & - \\
dpopm & -0.4359 & -0.7641 & 1.0000 & - & - & - & - \\
growvol & -0.3956 & -0.5131 & 0.4805 & 1.0000 & - & - & - \\
lgfreq & -0.2763 & 0.0057 & 0.0296 & -0.2557 & 1.0000 & - & - \\
hgfreq & -0.0085 & 0.1544 & -0.1771 & -0.2535 & 0.3494 & 1.0000 & - \\
pcgdpm & 0.5456 & 0.6955 & -0.5918 & -0.4740 & 0.0029 & -0.0014 & 1.0000 \\
\hline
\end{tabular}

Note: The average GDP per capita growth of the sample for each country over 1971-2000 is growth, growvol is the standard deviation of GDP per capita growth over 1971-2000, lrgdpch is the logarithm of GDP per capita in 1970, hgfreq is the number of years in 1971-2000 when GDP per capita growth was above average GDP per capita growth plus one standard deviation of GDP per capita growth, lgfreq is the number of years in 1971-2000 when GDP per capita growth was below average GDP per capita growth minus one standard deviation of GDP per capita growth, $d p o p m$ is the average population growth rate over 1971-2000, and pcgdpm is the average ratio of private credit to GDP over 1971-2000.

Source: Author's analysis is on the basis of the data described in the text.

\section{FUNDING}

This article was completed while the author was a Ph.D. student at the Department and Laboratory of Applied and Theoretical Economics (DELTA), Paris, France.

\section{REFERENCES}

Acemoglu, D., and F. Zilibotti. 1997. "Was Prometheus Unbound by Chance? Risk, Diversification and Growth.” Journal of Political Economy 105(4):709-51.

Aghion, P., A. Banerjee, and T Piketty. 1999. “Dualism and Macroeconomic Volatility.” Quarterly Journal of Economics 114(4):1359-97.

Albuquerque, R., and H. Hopenhayn. 2004. "Optimal Lending Contracts and Firms Dynamics." Review of Economic Studies 71(2):285-315.

Baig, T., and I. Goldfajn. 2002. "Monetary Policy in the Aftermath of Currency Crises: The Case of Asia." Review of International Economics 10(1):92-112.

Barclay, M., and C. Smith. 1995. “The Maturity Structure of Corporate Debt." Journal of Finance 50(2):609-31.

Beck, T., A. Demirgüç-Kunt, and R. Levine. 1999. “A New Database on Financial Development and Structure." World Bank Economic Review 14(3):597-605.

Bernanke, B., and M. Gertler. 1989. "Agency Costs, Net Worth, and Business Fluctuations.” American Economic Review 79(1):14-31.

Chang, R., and A. Velasco. 2000. "Banks, Debt Maturity and Financial Crises." Journal of International Economics 51(1):169-94.

Chang, R., and A Velasco. 2001. “A Model of Financial Crises in Emerging Markets.” Quarterly Journal of Economics 116(2):489-517.

Claessens, S., S. Djankov, and L. Lang. 1998. "East Asian Corporates: Growth, Financing and Risks over the Last Decade.” Policy Research Working Paper 2017. World Bank, Washington, D.C. 
Claessens, S., S. Djankov, and T. Nenova. 2000. "Corporate Growth Risk around the World.” Policy Research Working Paper 2271. World Bank, Washington, D.C.

Corsetti, G., P. Pesenti, and N. Roubini. 1999. "What Causes the Asian Currency and Financial Crises? A Macroeconomic Overview." Japan and the World Economy 11(3):305-73.

Demirgüç-Kunt, A., and V. Maksimovic. 1999. "Institutions, Financial Markets, and Firm Debt." Journal of Financial Economics 54(3):295-336.

Diamond, D. 1991. "Debt Maturity Structure and Liquidity Risk.” Quarterly Journal of Economics 106(3):709-37.

Diamond, D., and P. Dybvig. 1983. "Bank Runs, Deposit Insurance and Liquidity.” Journal of Political Economy 91(3):401-19.

Eichengreen, B., and R. Hausmann. 1999. "Exchange Rates and Financial Fragility.” NBER Working Paper 7418. Cambridge, MA: National Bureau of Economic Research.

Flannery, M. 1986. “Asymmetric Information and Risky Debt Maturity Choice.” Journal of Finance 41(1)19-37.

Furman, J., and J. Stiglitz. 1998. "Economic Crises: Evidence and Insights from East Asia.” Brookings Papers on Economic Activity 2:1-136.

Greenwald, B., and J. Stiglitz. 1993. "Financial Market Imperfections and Business Cycles.” Quarterly Journal of Economics 108(1):77-114.

Greenwood, J., and B. Jovanovic. 1990. "Financial Development, Growth, and the Distribution of Income." Journal of Political Economy 98(5):1076-107.

Heston, A., R. Summers, and B. Aten. 2002. "Penn World Table Version 6.1." Center for International Comparisons, University of Pennsylvania, Philadelphia, PA.

Jones, L., R. Manuelli, and E. Sachetti. 1999. “Technology and Policy Shocks in Models of Endogenous Growth.” NBER Working Paper 7063. Cambridge, MA: National Bureau of Economic Research.

Kale, J., and T. Noe. 1990. "Risky Debt Maturity Choice in a Sequential Game Equilibrium.” Journal of Financial Research 13(2):155-65.

Kiyotaki, N., and J. Moore. 1997. “Credit Cycles.” Journal of Political Economy 105(2):211-48.

Krugman, P. 1979. "A Model of Balance of Payments Crises.” Journal of Money Credit and Banking 11(3):311-25.

- 1999. "Balance Sheets, the Transfer Problem, and Financial Crises." International Tax and Public Finance 6(4):459-72.

Loayza, N., and V. Hnatkovska. 2004. "Volatility and Growth.” In J. Aizenman, and B. Pinto eds., Managing Economic Volatility and Crises: A Practitioner's Guide. Cambridge: Cambridge University Press.

Radelet, S., and J. Sachs. 1998. "The Onset of the East Asian Financial Crisis.” NBER Working Paper 6680. Cambridge, MA: National Bureau of Economic Research.

Ramey, G., and V. Ramey. 1995. "Cross-country Evidence on the Link between Volatility and Growth.” American Economic Review 85(5):1138-51.

Rancière, R., A. Tornell, and F. Westermann. (forthcoming, 2008). "Systemic Crises and Growth." Quarterly Journal of Economics.

Rey, P., and J. Stiglitz. 1993. "Short-term Contracts as a Monitoring Device." NBER Working Paper 4514. Cambridge, MA: National Bureau of Economic Research.

Rodrik, D., and A. Velasco. 1999. "Short-term Capital Flows.” In B. Pleskovic, and J. E. Stiglitz eds., Annual World Bank Conference on Development Economics, 1999. Washington, D.C.: World Bank.

Tornell, A., F. Westermann, and L. Martinez. 2004. "The Positive Link between Financial Liberalization, Growth and Crises.” Working Paper 1164. Munich: CESifo.

World Bank. 2005. World Development Indicators Database. Washington, D.C. 